Zusammenfassung. Auf der Basis von Bildern der verschiedenen Operationsphasen und -ergebnissen wird die Technik der Plastibell-Methode gezeigt. Sie bedeutet eine einfache, komplikationslose Möglichkeit zur Korrektur der angeborenen oder erworbenen Phimose und ist ebenso verwendbar bei routinemäßiger Beschneidung Neugeborener. Postoperativer Heilverlauf und Nachuntersuchungsergebnisse bei über 400 Fällen sind als gut zu bezeichnen. Das Plastibell-Verfahren, besonders gut im ambulanten Bereich durchführbar, wird als Methode der Wahl empfohlen.

Schlïsselwörter: Phimosenkorrektur - „Plastibell-Methode“.

\title{
171. Chirurgie des Hyperparathyreoidismus
}

\author{
G. Heberer, F. Spelsberg und B. Günther \\ Chirurgische Klinik der Universität München
}

\section{Surgery in Hyperparathyroidism}

Summary. From 1960 to 1975 a total of 117 patients were operated on for hyperparathyroidism; 87 percent of these suffered from primary hyperparathyroidism, 8 percent from secondary and 5 percent from tertiary hyperparathyroidism. Location of the parathyroid glands with adenomatous or hyperplastic changes was parathyroid in 76.4 percent of the cases of primary hyperparathyroidism, intrathyroidal in 6.2 percent, mediastinal in 10.7 percent and at other sites in 6.7 percent. Follow-up examination revealed 70 patients to be free of symptoms, while 14 had died from various causes. The early lethality was 6 percent.

Key words: Hyperparathyroidism - Morphology - Location - Results.

Zusammenfassung. Von 1960-1975 wurden 117 Patienten wegen eines Hyperparathyreoidismus operiert, davon $87 \%$ wegen primären, $8 \%$ wegen sekundären und $5 \%$ wegen tertiären. Beim primären Hyperparathyreoidismus waren die adenomatös bzw. hyperplastisch veränderten Epithelkörperchen in $76,4 \%$ parathyreoidal, in $6,2 \%$ intrathyreoidal, in $10,7 \%$ mediastinal und in $6,7 \%$ an anderer Stelle lokalisiert. Bei der Nachkontrolle waren 70 Patienten beschwerdefrei, 14 meist an anderen Ursachen verstorben. Die Frühletalität betrug $6 \%$.

Schlïsselwörter: Hyperparathyreoidismus - Morphologie - Lokalisation - Ergebnisse.

\section{Amazonensyndrom}

\author{
W. D. Mühlbauer und K. Wangerin
}

Abteilung für Plastische Chirurgie am Klinikum rechts der Isar der Technischen Universität München

\section{Amazon Syndrome}

Summary. The Amazon Syndrom describes a complex malformation comprising unilateral agenesis of the female breast, ipsilateral symbrachydactyly with various soft-tissue, muscular, and skeletal defects. Analysis of 36 of the authors own cases, revealed agenesis of one breast as the main symptom 